\title{
NORMATYWNE UWARUNKOWANIA REALIZOWANIA KOMPETENCJI PRAWODAWCZYCH PRZEZ ORGANY JEDNOSTEK SAMORZĄDU TERYTORIALNEGO
}

Kategoria władczych kompetencji organów administracji publicznej pozostaje w ścisłym i nierozerwalnym związku z ogólnym pojęciem władztwa administracyjnego ${ }^{1}$. Władztwo administracyjne stanowi „zawężone $\mathrm{z}$ uwagi na kryterium podmiotowe władztwo państwowe (publiczne) przysługujące niepodzielnie państwu jako organizacji, a wynikające z władzy państwowej (publicznej), sprowadzające się do zakresu mocy normatywnie wyznaczonych atrybutów, w jakie wyposażona została administracja publiczna, przejawiajace się w ustalaniu sfery praw i obowiązków podmiotów znajdujących się poza jej organizacja, bądź też w jej organizacji”" ${ }^{2}$. Władztwo publiczne przysługujące państwu jako organizacji może być zatem atrybutem i innych podmiotów działających w ramach tej organizacji, w tym również działających na zasadzie decentralizacji jednostek samorząu terytorialnego.

Elementami przesądzającymi o mocy władztwa administracyjnego podmiotów wykonujących administrację publiczna, a także o efektach jego realizacji sa podstawy normatywne zakodowane w aktach rangi ustawowej. Władztwo administracyjne organów jednostek samorządu terytorialnego jest więc - tak jak władztwo wszystkich organów administracji publicznej - określone przez normy ustawowe kreujące kompetencje tych organów i wskazujące, jak z nich korzystać (jest zatem określone przez normy różnego typu). Analizując determinanty realizowania władztwa administracyjnego przez organy jednostek samorządu terytorialnego, należy mieć na uwadze zwłaszcza te normy usta-

${ }^{1}$ Omawiana $\mathrm{w}$ artykule problematyka prezentowana jest $\mathrm{z}$ perspektywy nauki prawa administracyjnego i opiera się na przyjmowanych $\mathrm{w}$ tej nauce ustaleniach $\mathrm{w}$ kwestii rozumienia kompetencji administracyjnej. Nawiązuje do ustaleń teorii prawa jedynie w zakresie, w jakim ustalenia te dotychczas inspirowały naukę prawa administracyjnego do dokonywania wyborów takich ujęć teoretycznoprawnych, które najlepiej odpowiadają intuicjom i potrzebom prawa administracyjnego. Przedstawione opracowanie nie jest zatem głosem w dyskusji prowadzonej z perspektywy teorii prawa a dotyczącej kompetencji i normy kompetencyjnej.

${ }^{2}$ M. Krawczyk, Podstawy władztwa administracyjnego, Kraków 2014, s. 338 (nieopublikowana rozprawa doktorska). 
wowe, które określają prawa i obowiązki wspólnoty samorządowej, wyznaczają zakres jej samodzielności w realizowaniu władzy publicznej, a także wyznaczają zakres powierzonych jej do wykonania zadań publicznych. Niewatpliwie normy takie determinują sposób czynienia użytku z kompetencji organów jednostek samorządu terytorialnego.

Rozważania prezentowanego opracowania dotyczą obszarów, w których władztwo administracyjne realizowane jest w sferze zewnętrznej w procesach tworzenia prawa w ramach kompetencji prawodawczych.

W analizie dotyczącej kompetencji prawodawczych organów jednostek samorządu terytorialnego nie należy zatem abstrahować od sytuacji prawnej tych jednostek (wspólnot samorządowych), gdy się uwzględni unormowania Konstytucji RP zawarte w art. 163, art. 165 ust. 2, art. 169 ust. 1, art. 171 ust. 1, art. 87 ust. 2, art. 94, statuujace chroniona prawnie ich samodzielność. Władztwo administracyjne tych organów pozostaje w związku z sytuacja prawną wspólnot samorządowych, a w konsekwencji ono samo, jak i charakter kompetencji organów jednostek samorządu terytorialnego można analizować z perspektywy podmiotowości publicznoprawnej tych wspólnot.

Podmiotowość publicznoprawna wspólnot samorządowych, zgodnie z państwową teorią samorządu, jest konsekwencją podmiotowości prawnej państwa ${ }^{3}$ i jako taka wyznaczana jest ich samodzielnością i władztwem publicznym, jakie uzyskuja one w drodze ustawowej. Skoro więc atrybut władztwa publicznego wiązany jest z samodzielnością wspólnoty samorządowej wyznaczoną jej prawami i obowiązami publicznoprawnymi, to uprawnione jest twierdzenie, że publiczne prawa podmiotowe i obowiązki takiej wspólnoty uzasadniają jej władztwo publiczne i wyznaczaja jego granice.

Prawa te i obowiązki wynikaja wyłącznie $\mathrm{z}$ obowiązujących norm prawnych, co oznacza, że i zakres władztwa publicznego wspólnoty samorządowej jest ściśle zdeterminowany prawnie ${ }^{4}$. Nie zapominając o tym, że wspólnoty samorządowe są wspólnotami publicznoprawnymi w ramach szerszej tego rodzaju wspólnoty, jaką jest państwo, należy mieć na uwadze, że o ile sposób wykonywania władztwa publicznego i samo władztwo publiczne państwa sa określane przez jego organy ustawodawcze, o tyle na zakres władztwa publicznego wspólnoty samorządowej i sposób jego realizacji ona sama nie ma i nie

${ }^{3}$ T. Bigo, Zwiazki publicznoprawne w świetle ustawodawstwa polskiego, Warszawa 1928, s. 140-141; J. Jendrośka, Teorie samorzadu terytorialnego, w: J. Boć (red.), Prawo administracyjne, Wrocław 2004, s. 185; I. Skrzydło-Niżnik, Ochrona publicznych praw podmiotowych obywateli a instytucja Naczelnego Sqdu Administracyjnego, „Casus” 1997, nr 5, s. XIV.

${ }_{4}^{4}$ Art. 16 ust. 2 Konstytucji RP, art. 2 ust. 1 ustawy z 8 marca 1990 r. o samorządzie gminnym (t.jedn.: Dz. U. 2013, poz. 594; dalej jako: ustawa o samorządzie gminnym), art. 2 ust. 1 ustawy z 5 czerwca 1998 r. o samorządzie powiatowym (t.jedn.: Dz. U. 2013, poz. 595; dalej jako: ustawa o samorządzie powiatowym), art. 6 ust. 1 pkt 1 ustawy z 5 czerwca 1998 r. o samorządzie województwa (t.jedn.: Dz. U. 2013, poz. 596; dalej jako: ustawa o samorządzie województwa). 
może mieć decydującego i wyłącznego wpływu. Władztwo publiczne wspólnoty samorządowej zdeterminowane jest regulacjami ustawowymi, a skoro jest ona osobą prawna, to oznacza, że władztwo to może być wykonywane przez organy takiej wspólnoty, o ile zostaną one do tego upoważnione przez normy obowiązującego prawa. O jego istnieniu i zakresie decyduje ustawodawca kreujący z jednej strony kompetencje organów wspólnoty samorządowej, a z drugiej wyznaczający granice samodzielności tej wspólnoty. Władztwo publiczne nie jest więc naturalna, „przedprawną" cechą wspólnoty samorządowej i nie jest „konkurencyjne” wobec władztwa państwa

Pozycja prawna wspólnot samorządowych determinowana ich konstytucyjnie zagwarantowana samodzielnością i pozycja prawna państwa wyznaczana jego suwerennościa nie mogą być utożsamiane. Wpływa to również na charakter „produktu” będacego wynikiem realizowania przez organy wspólnot samorządowych ich kompetencji prawodawczych.

\section{III}

Obierając na wstępie i wyłącznie jako punkt wyjścia dalszych rozważań ogólna perspektywę nawiązująca do wypracowanej w nauce prawa administracyjnego konstrukcji kompetencji administracyjnej ${ }^{6}$ in genere, tj. bez odwoływania się w tym miejscu do specyfiki realizowania kompetencji w zakresie tworzenia prawa, należy przyjąć, że z istoty kompetencji administracyjnej wynika, że jakiekolwiek działania publicznoprawne wspólnoty samorządowej nie

${ }^{5}$ I. Skrzydło-Niżnik, Model ustroju samorzqdu terytorialnego w Polsce na tle zagadnień ustrojowego prawa administracyjnego, Kraków 2007, s. 311.

${ }^{6}$ Kategoria kompetencji administracyjnej, w tym jej źródła, istota i charakter, zgodnie z poglądami doktryny prawa administracyjnego nie jest tożsama z kategorią kompetencji w jej różnych rozumieniach prezentowanych w teorii prawa. Zwłaszcza koncepcja normy kompetencyjnej Z. Ziembińskiego znacznie odbiega od ugruntowanej w doktrynie prawa administracyjnego konwencji, w myśl której adresatem normy kompetencyjnej nie jest podmiot podległy kompetencji, lecz podmiot, który uzyskuje kompetencję. Zob. T. Rabska, W poszukiwaniu pojęcia „,kompetencji normodawczej" organów administracji państwowej, AUW, Prawo CXLIII, Wrocław 1985, s. 259 i n.; W. Góralczyk, Zasada kompetencyjności w prawie administracyjnym, Warszawa 1986, s. 61. Również w teorii prawa wskazuje się, że rozumienie kompetencji przez koncepcje redukujące pojęcie normy zakazu (nakazu) postępowania nie jest nastawione na analizę relacji najistotniejszej dla administratywistyki, tj. relacji pionowej między podmiotem administrującym a podmiotem administrowanym, a tym samym nie spełnia wymogu operatywności w analizowaniu tej relacji, zachodzącej pomiędzy działającym podmiotem posiadającym kompetencję a podmiotem tej kompetencji podległym. Zob. M. Matczak, Kompetencja organu administracji publicznej, Kraków 2004, s. 118119, 125-126. Kompetencja administracyjna traktowana jest w doktrynie jako nowa jakość właściwa prawu administracyjnemu. Zob. D. Mazurkiewicz, Pojęcie kompetencji w prawie administracyjnym, „Państwo i Prawo” 43, 1988, z. 3, s. 72. Przyjmuje się, że kompetencja oznacza upoważnienie organu do podejmowania czynności administracyjnoprawnych w imieniu państwa wobec innych podmiotów. Zob. T. Rabska, Prawny mechanizm kierowania gospodarka, Wrocław-Warszawa-Kraków 1990, s. 108, 114. Por. też: J. Borkowski, Zagadnienie kompetencji ogólnej i szczególnej w prawie administracyjnym, „Studia Prawnicze” 1971, z. 31, s. 61-62; J. Boć, Pojęcie kompetencji, w: idem (red.), op. cit., s. 143; W. Jakimowicz, Wyktadnia w prawie administracyjnym, Warszawa 2006, s. 397-410; J. Zimmermann, Prawo administracyjne, Kraków 2014, s. 142. 
mogą być podejmowane poza granicami kompetencji jej organów. Nawet prawnie określona samodzielność wspólnoty samorządowej nie może być realizowana bez kompetencji administracyjnych, ani też poza ich zakresem. Atrybut samodzielności nie może stanowić podstawy do „doszukiwania się” w systemie prawnym norm kompetencyjnych, w tym norm kompetencji prawodawczej i uzasadniać ich jakiegokolwiek domniemywania, może natomiast mieć wpływ na sposób realizowania istniejących kompetencji administracyjnych, oczywiście sposób wyznaczony wyłącznie przez kryterium legalności (a nie również przez inne kryteria dopuszczalne prawnie w stosunku do podmiotów niesamodzielnych).

Kompetencje organów administracji publicznej, jeżeli je rozumieć jako upoważnienia ${ }^{7}$ do określonego zachowania skierowane do organów administracji

${ }^{7}$ Odwołuję się w tym miejscu do prezentowanego w doktrynie stanowiska, zgodnie z którym: „kompetencja prawna jest pojęciem poznawczo pierwotnym w stosunku do teoretycznoprawnej konstrukcji znanej jako tzw. norma kompetencyjna. Normy prawne powstają w następstwie wykonania reguł wyposażających w kompetencję [...]. Odróżniać jednak należy reguły, łączone tu pojęciowo z kompetencja, i normy jako wypowiedzi będące rezultatem wykonania kompetencji. Konstrukcja normy kompetencyjnej zakłada natomiast redukcję reguł (kompetencji) do norm powodując zarazem zniekształcenie typowego kształtu językowego normy, co powoduje cały szereg komplikacji przy próbach adaptacji tej konstrukcji w naukach szczegółowych". Zob.: A. Bator, Użycie normy prawnej $w$ regulacji stosunków gospodarczych, Wrocław 2000, s. 314. Nawiązuję zatem do niepredyktywnej koncepcji kompetencji i (norm) reguł ją wyznaczających w kształcie zaproponowanym przez M. Matczaka. Zob. M. Matczak, op. cit., s. 145-146. Normę kompetencyjną w ujęciu Z. Ziembińskiego można tu rozpisać na regułę dokonywania czynności konwencjonalnej (regułę kompetencyjna) oraz normę postępowania będącą efektem skorzystania z tej reguły (w sytuacji, w której do ustanowienia normy postępowania dochodzi). W ujęciu niepredyktywnym uprawnione byłoby stwierdzenie, że wśród norm prawnych zakodowanych w tekście prawnym możliwe jest wyróżnienie zarówno norm postępowania, w sytuacji skorzystania z reguły kompetencyjnej, które to normy zawierają wyrażenie nakazu lub zakazu, oraz właśnie reguł kompetencyjnych dotyczących możliwości dokonania czynności konwencjonalnych. Reguła kompetencyjna będąca również normą prawną może być w tym ujęciu nazwana normą kompetencyjna. Ze względu na tego rodzaju regułę określony podmiot czy podmioty uzyskują upoważnienie do dokonywania czynności, której będzie przypisywany charakter danego rodzaju czynności konwencjonalnej. Upoważnienie to $\mathrm{w}$ prezentowanym ujęciu można nazwać kompetencją. Kompetencja w ujęciu teoretycznoprawnym jest więc sytuacją prawną podmiotu, który dokonując określonej czynności $C$ na mocy reguły kompetencyjnej $R$, dokonuje skutecznie czynności konwencjonalnej $C k$, a przez to osiaga skutek $\mathrm{Cm}$ polegający na ustanowieniu (albo zmianie istniejącej, albo derogacji) normy postępowania $N$ lub reguły kompetencyjnej $R$ (wówczas można mówić o kompetencjach normotwórczych, wśród których mieści się również kompetencja do wydawania aktów administracyjnych) bądź skutek polegający na aktualizacji obowiązku określonego w już ustanowionej normie postępowania $N$ (wówczas można mówić o kompetencjach do zaktualizowania obowiązku, np. na skutek wniosku o wszczęcie postępowania organ jest zobowiązany ze względu na normę wcześniej już ustanowioną podjąć odpowiednie czynności procesowe), bądź wreszcie skutek polegający na wywołaniu innego skutku konwencjonalnego będącego niezbędnym elementem innej reguły kompetencyjnej $R$ (wówczas można mówić o kompetencjach pomocniczych, np. wydanie przez organ postanowienia w trybie art. 106 k.p.a. jest niezbędnym elementem proceduralnym wydania decyzji administracyjnej przez inny organ). Norma kompetencyjna (reguła kompetencyjna) adresowana jest tu nie do podmiotu, w stosunku do którego wykonywana jest czynność konwencjonalna (jak to ma miejsce w ujęciu Z. Ziembińskiego), lecz do podmiotu uzyskującego kompetencję i dokonującego w oparciu o tę kompetencję określonej czynności konwencjonalnej. Niewątpliwie taki kształt normy kompetencyjnej bardziej odpowiada szczególnemu charakterowi relacji prawnych w prawie administracyjnym. 
publicznej przez ustawodawcę, wynikają w pierwszej kolejności z norm kompetencyjnych. Oznacza to, że normy kompetencyjne stanowią niewatpliwie zasadniczy - ale nie jedyny - element podstawy normatywnej kompetencji administracyjnych, w tym również kompetencji prawodawczych organów jednostek samorządu terytorialnego.

Samo ustalenie upoważnienia ustawowego do określonego zachowania organu pozwala określić zakres kompetencji, nie daje jednak odpowiedzi na pytanie, jak tę kompetencję wykonywać, a zwłaszcza jak i jakie wartości realizować w jej ramach. Odpowiedź na to pytanie determinuje w znacznym stopniu podmiotowość publicznoprawna wspólnoty samorządowej związana z zakresem jej praw i obowiązków (w tym zadań) i oparta na niej samodzielność tego rodzaju wspólnoty.

Należy przyjąć, że specyfika władztwa wspólnoty samorządowej przejawia się w przyznaniu jej przez ustawodawcę określonej swobody co do sposobu realizowania kompetencji administracyjnych. Sposób realizacji kompetencji wyznaczają normy zadaniowe, a wspólnym mianownikiem wynikających z nich zadań w przypadku podmiotów wykonujących administrację publiczna jest dążenie do realizacji interesu publicznego. Nawiązując w tym kontekście do sygnalizowanych już wyżej kwestii związanych z atrybutem samodzielności wspólnot samorządowych, należy podkreślić, że samodzielność ta jest „zaledwie kwalifikacją (ocena) możliwości wykonywania kompetencji publicznoprawnych i uprawnień prywatnoprawnych, nie zaś samodzielnym dobrem", a zadania publiczne (zadania administracji publicznej) to normatywne określenie zachowań aparatu administracji koniecznych do urzeczywistniania określonego celu państwa, za pomocą wyznaczonych środków i form działania, to także normatywne zobowiązanie administracji do realizacji wytyczonego celu państwa przez określone stosowanie wyznaczonych środków ${ }^{9}$. Można zatem przyjąć, że zadania publiczne to zadania, które będąc ukierunkowane na zaspokajanie potrzeb poszczególnych wspólnot terytorialnych, służą realizacji dobra wspólnego.

Również i te ogólne uwagi odnoszą się do kompetencji zarówno w zakresie stosowania prawa, jak i w zakresie jego tworzenia.

\footnotetext{
${ }^{8}$ W. Kisiel, Komentarz do art. 2 ustawy o samorzqdzie gminnym, w: P. Chmielnicki (red.), Komentarz do ustawy o samorzadzie gminnym, Warszawa 2004, s. 43.

${ }^{9}$ M. Górski, Pojęcia - „funkcje administracji państwowej” $i$,zadania administracji państwowej”, „Acta Universitatis Lodziensis. Folia Iuridica” 52, 1992, s. 170-172. Normy zadaniowe skierowane do organów administracji publicznej, a nie do adresatów ich działań określają zadania sformułowane najczęściej w powiązaniu z celem działania administracji. W doktrynie prawa administracyjnego trafnie wskazuje się, że określenie zadania i określenie celu działania podmiotu administracji publicznej jest jednoznaczne $\mathrm{z}$ nałożeniem na ten podmiot obowiązku wykonania danego zadania lub obowiązku osiąnięcia wyznaczonego celu. Zob. J. Zimmermann, op. cit., s. 53. Wynika to z założenia, że określony stan rzeczy, którego osiagnięcie nakazuje norma zadaniowa, ma być osiagnięty bez względu na panujące okoliczności, dlatego też w wypadku tego rodzaju norm zazwyczaj nie określa się okoliczności, w których dane działanie ma być dokonywane. Zob. M. Matczak, op. cit., s. 192. Obowiązku tego nie zmienia fakultatywny charakter niektórych zadań. Zob. na temat działań fakultatywnych organów administracji i fakultatywności działania tych organów M. Oleś, Fakultatywne działania administracji publicznej, (nieopublikowana rozprawa doktorska), Kraków 2014, s. 240.
} 


\section{IV}

Potrzeba ochrony różnego rodzaju interesów pozostaje w ścisłym związku z ustawową regulacją zadań i kompetencji administracyjnych organów poszczególnych szczebli administracji samorządowej, wiąże się zatem z zakresem samodzielności określonej wspólnoty samorządowej. Władztwo wspólnoty można zatem redukować do władztwa jej organów i rozważać w kontekście kategorii kompetencji administracyjnej rozumianej jako swojego rodzaju wspólny mianownik obejmujący jednocześnie kompetencję w ogólnym znaczeniu upoważnienia wynikająca z normy kompetencyjnej (reguły kompetencyjnej) oraz generalny obowiązek realizacji interesu publicznego wynikający z normy postępowania (rozumianej jako norma nakazująca [zakazująca] określonym podmiotom dokonywania czynności psychofizycznych lub czynności prawnych) ${ }^{10}$ skierowanej do organu administracji. Specyfika władztwa wspólnoty samorządowej koncentruje się jednak zasadniczo na jej zadaniach wynikajacych z norm zadaniowych, gdyż właśnie zadania poszczególnych wspólnot samorządowych determinuja ich samodzielność i granice tej samodzielności, a tym samym odróżniają od innych wspólnot terytorialnych.

Kompetencja administracyjna jako określona możność działania determinowana jest zarówno normą kompetencyjną (regułą kompetencyjna), jak i normą zadaniową stanowiąca źródło obowiązku realizacji interesu publicznego przez organ administracji publicznej, a w konsekwencji wskazującą na sposób czynienia użytku z kompetencji. Stwierdzenie kompetencji administracyjnej jest punktem wyjścia do ustalenia istnienia i granic władztwa wspólnoty, $\mathrm{w}$ tym granic ingerencji organu administracji w określoną prawem sferę wolności jednostki.

Dla porządku należy odnotować wypracowane w doktrynie i orzecznictwie stanowisko, zgodnie z którym dekodowanie zarówno norm kompetencyjnych, jak i norm zadaniowych może mieć miejsce wyłącznie na gruncie przepisów rangi ustawowej, a zwłaszcza nie ma podstaw do dekodowania powyższych norm z przepisów podustawowych ${ }^{11}$. Ponadto przepisy kompetencyjne podlegają ścisłej wykładni językowej ${ }^{12}$, a zwłaszcza na etapie odkodowywania z nich norm kompetencyjnych należy zrezygnować z metody wykładni celowościowej $^{13}$, a nawet - idacc dalej - wykluczyć dopuszczalność stosowania jakiejkol-

${ }^{10}$ Z. Ziembiński, Kompetencja i norma kompetencyjna, „Ruch Prawniczy, Ekonomiczny i Socjologiczny" 31, 1969, z. 4, s. 37 .

11 J. S. Langrod, Instytucje prawa administracyjnego. Zarys części ogólnej, Kraków 2003, s. 291; J. Zimmermann, op. cit., s. 87.

${ }_{12}$ Wyrok TK z 25 maja 1998 r., U 19/97, OTK 1998, nr 4, poz. 47, Lex, nr 33148; wyroki NSA: z 3 lipca 2014 r., II OSK 281/14, Lex, nr 1477420 i z 10 maja 2011 r., II OSK 2301/10, Lex, nr 992513.

${ }_{13}$ Wyrok NSA z 21 maja 1999 r., I SA/Lu 248/98, Lex, nr 37836; wyroki TK: z 21 lutego 2005 r., U 3/04, OTK-A 2005, nr 2, poz. 16; Lex, nr 146782 i z 6 marca 2002 r., P 7/00, OTK ZU 2002, nr 2, poz. 13, Lex, nr 54047. 
wiek wykładni poza językową ${ }^{14}$. Wyłączone jest jakiekolwiek domniemywanie kompetencji ${ }^{15}$.

Tak jak z norm kompetencyjnych (reguł kompetencyjnych) wynikają kompetencje organów administracji rozumiane jako określone możności działania, tak z norm zadaniowych wynika pojęciowo odrębna kategoria zadań tych organów, czyli ich obowiązków. Oznacza to, że tak jak normy kompetencyjne (reguły kompetencyjne) nie mogą być źródłem obowiązków organów administracji, tak z norm zadaniowych nie mogą wynikać kompetencje tych organów, a co za tym idzie - zadania organów administracji publicznej nie mogą być źródłami ich kompetencji. Normy zadaniowe w przeciwieństwie do norm kompetencyjnych nie mają charakteru upoważniającego, gdyż z określenia zadań nie wynika automatycznie zdolność do podejmowania określonych działań ${ }^{16}$.

Władztwo publiczne wspólnoty samorządowej nie wynika zatem wyłącznie z norm zadaniowych określających zadania publiczne powierzone do wykonania wspólnocie, co oznacza istotne osłabienie argumentu „samodzielności wspólnoty” w ocenie mocy jej władztwa. Konsekwencją tego, że samodzielność wspólnoty samorządowej jest kategorią prawną powiązaną z kategorią norm zadaniowych i determinowaną wyłącznie przez ustawodawcę, jest to, że o istnieniu i zakresie tej samodzielności nie może decydować sama ta wspólnota. Tym samym argument samodzielności jest argumentem obiektywnym opartym na konkretnych normach obowiązującego prawa, podlegajacym pełnej weryfikacji w ramach kontroli nadzorczej lub sądowoadministracyjnej, tak jak pełnej kontroli podlegaja procesy wykładni, a zwłaszcza samodzielność wspólnoty samorządowej nie może być traktowana jako zasadnicza i samoistna podstawa jej władztwa. Samodzielność wspólnoty samorządowej stanowi obiektywną determinantę realizowania kompetencji administracyjnej opartej na konkretnej normie kompetencyjnej. Normy zadaniowe - tak jak normy kompetencyjne - należą do wyłącznej materii ustawowej, co oznacza, że wspólnota nie może sama - w braku wyraźnego upoważnienia ustawowego - decydować o sposobie realizowania tej samodzielności. Nie jest w konsekwencji również dopuszczalna kreacyjna działalność organów wspólnoty w zakresie jej władztwa. Pewien obszar swobody może wynikać jedynie z woli ustawodawcy: może konstruować przepisy prawne, w których zakodowane są normy zadaniowe, posługując się kategorią pojęć nieoznaczonych, często wymagających przeprowadzenia szerszych procesów wykładni. Każda czynność organu wspólnoty samorządowej podejmowana w ramach właściwego jej władztwa wymaga

14 Wyrok WSA we Wrocławiu z 26 stycznia 2005 r., IV SA/Wr 807/04, Lex, nr 144530; uchwała NSA z 15 grudnia 2004 r., FPS 2/04, ONSiWSA 2005, nr 1, poz. 1, Lex, nr 137421; J. Trzciński, Glosa do uchwaty SN z dnia 4 lipca 2001 r., III ZP 12/01, „Rzeczpospolita” 2001, nr 12, s. 5.

${ }_{15}$ M. Zimmermann, Z rozważań nad postępowaniem jurysdykcyjnym i pojęciem strony $w$ kodeksie postepowania administracyjnego, w: Księga Pamiatkowa ku czci Kamila Stefki, WarszawaWrocław 1967, s. 443-444; uchwała 7 sędziów NSA z 15 grudnia 2004 r., FPS 2/04, ONSAiWSA 2005, nr 1, poz. 1, Lex, nr 137421; wyrok TK z 1 czerwca 2004 r., U 2/03, OTK-A 2004, nr 6, poz. 54, Lex, nr 119001; postanowienie 7 sędziów SN z 18 stycznia 2005 r., WK 22/04, OSNKW 2005, nr 3, poz. 29; Lex, nr 145163.

${ }_{16}$ W. Góralczyk, op. cit., s. 41; T. Rabska, Prawny mechanizm..., s. 110; K. Defecińska, Spory o właściwość organu administracji publicznej, Warszawa 2000, s. 8; M. Matczak, op. cit., s. 186-187. 
konkretnego przepisu upoważniającego, tj. przepisu, z którego wynika norma kompetencyjna. Pogląd ten stanowi konsekwencję założenia niedopuszczalności utożsamiania samodzielności wspólnoty samorządowej z suwerennościa, która nie jest i nie może być w świetle Konstytucji RP przypisywana jakiemukolwiek innemu podmiotowi niż państwo.

Normy kompetencyjne i normy zadaniowe będące podstawami normatywnymi kompetencji organów administracji publicznej stanowią również (w sposób właściwy dla każdego z tych typów norm) determinanty realizowania kompetencji administracyjnych, a specyfika kompetencji organów wspólnot samorządowych jest ściśle powiązana ze specyfiką zadań powierzanych przez ustawodawcę do realizacji podmiotom korzystającym z atrybutu samodzielności.

$\mathrm{W}$ analizie normatywnych determinant realizowania kompetencji prawodawczych przez organy jednostek samorządu terytorialnego warto zwrócić uwagę na jeszcze jedną kategorię norm. Skoro bowiem, poszukując odpowiedzi na pytanie, jak należy korzystać z upoważnienia ustawowego, uzasadnione jest odwoływanie się do innych norm niż te, z których wynika samo upoważnienie, to nie ma powodów, aby poprzestawać w tym zakresie jedynie na odnotowaniu istnienia norm zadaniowych. Równie uprawnione i pożądane jest odwoływanie się do norm, które determinują formalny aspekt korzystania z upoważnienia ustawowego, tj. norm, które wskazując na kształt, jaki powinien uzyskać efekt zrealizowania kompetencji, wyznaczają określone obowiązki organu dążenia do uzyskania tego efektu. Potrzeba nadawania określonej formy przejawom zachowania organów wiąże się ściśle ze służebną wobec norm materialnych rolą norm procesowych i norm określających formy działania ${ }^{17}$. Należy przyjąć, że realizowanie kompetencji władczych w formach określonych przez ustawodawcę służy przede wszystkim zapewnieniu efektywnej i jak najszerszej weryfikacji zachowań organów administracji publicznej przez podmioty powołane do ich kontrolowania, w tym zwłaszcza przez sądy administracyjne i organy nadzoru. Uwarunkowania normatywne o charakterze formalnym regulujące stopień sformalizowania władczej aktywności nie tyle są podstawami władztwa administracyjnego w ścisłym znaczeniu, ile determinantami pozwalającymi uskuteczniać (formalnie) to władztwo i gwarantujaccymi weryfikowalność tego działania ${ }^{18}$.

Dostrzegalne nieeksponowanie kwestii determinant formalnoprawnych w rozważaniach na temat kompetencji do rozstrzygania indywidualnych spraw administracyjnych można zrozumieć, skoro forma indywidualnych aktów administracyjnych jest od wielu dziesięcioleci nie tylko prawnie uregulowana w Kodeksie postępowania administracyjnego, lecz również zakorzeniona w powszechnej świadomości przedstawicieli doktryny i orzecznictwa, czego

${ }^{17} \mathrm{Na}$ temat norm procesowych i norm określających formy działania zob. J. Zimmermann, op. cit., s. 54.

${ }^{18}$ M. Krawczyk, op. cit., s. 227. 
najlepszym przykładem jest zaakceptowanie przez sądy i naukę teoretycznej konstrukcji domniemania formy decyzji administracyjnej ${ }^{19}$. Przyjmuje się tę konstrukcję, słusznie wywodząc, że zaistnienie indywidualnej sprawy administracyjnej implikuje formę jej rozstrzygnięcia (gdy ustawodawca milczy w tym zakresie), którą jest decyzja administracyjna, z trafnym uzasadnieniem, że konstrukcja ta służy zapewnieniu najpełniejszej kontroli instancyjnej i sądowej działania organów administracji publicznej w indywidualnych sprawach. Przyjęcie bowiem, że określony akt jest decyzją administracyjna, pozwala dokonać kontroli sposobu procedowania przez organ w określonej sprawie, a także poznać motywy jego działania i dokonać ich oceny, czyli w istocie zweryfikować sposób czynienia użytku z kompetencji administracyjnej. Naruszenie przepisów postępowania administracyjnego w tym zakresie może uzasadniać uchylenie przez sąd administracyjny decyzji na podstawie art. $145 \S 1$ pkt 1 lit. c Prawa o postępowania przed sądami administracyjnymi ${ }^{20}$.

Obowiązki wynikajace z norm określających formalne aspekty działania organów administracji publicznej można rozumieć jako kierowane do organów administracji publicznej obowiązki takiego realizowania kompetencji administracyjnych, które sposób ich realizacji uczyni w jak największym stopniu przejrzystym i poddającym się weryfikacji. Prawidłowość odczytania przez organ z przepisów prawnych upoważnień do niego kierowanych, a także zadań przewidzianych do zrealizowania w ramach tych upoważnień, jak i wskazujących na sposób czynienia użytku z upoważnień, można w pełni skontrolować dopiero wtedy, gdy pozna się motywy działania organu i odniesie je do wymogów obowiązującego prawa. W tym aspekcie można traktować normy procesowe i określające formy działania jako determinanty normatywne czynienia użytku z kompetencji administracyjnych, a znaczenie obowiązków wynikających z tych norm należy uwypuklać przede wszystkim tam, gdzie „formalna” regulacja prawna nie jest tak kompleksowa, jak w Kodeksie postępowania administracyjnego albo w ogóle jej nie ma.

Kompetencje prawodawcze wynikają z norm kompetencji prawodawczej. Jak wskazuje Mariusz Bogusz: „,norma kompetencji prawodawczej to norma prawna, która przyznaje określonemu organowi państwa kompetencję prawo-

${ }^{19}$ Konstrukcja domniemania formy decyzji administracyjnej odnosi się wyłącznie do formy działania organu administracji rozstrzygającego sprawę administracyjna, a nie do jego kompetencji w zakresie rozstrzygania tego rodzaju sprawy, bądź podstaw materialnoprawnych rozstrzygnięcia, a w konsekwencji nie może być traktowana jako usprawiedliwiająca domniemywanie kompetencji organu administracji publicznej lub podstaw prawnych jego działania. Na temat koncepcji domniemania formy decyzji administracyjnej zob. J. Jendrośka, B. Adamiak, Glosa do wyroku NSA $z$ dnia 27 kwietnia 1987 r., SA 767/81, OSPiKA 1983, poz. 109, s. 257; J. Zimmermann, Polska jurysdykcja administracyjna, Warszawa 1996, s. 138-141; idem, Prawo..., s. 334-335.

${ }^{20}$ Ustawa z 30 sierpnia 2002 r. - Prawo o postępowaniu przed sądami administracyjnymi, t.jedn.: Dz. U. 2012, poz. 270 ze zm. (dalej jako: Prawo o postępowaniu przed sądami administracyjnymi). 
dawcza, tj. przyznaje mu uprawnienie lub nakłada obowiązek ustanowienia (uchylenia bądź zmiany) normy prawnej o charakterze generalno-abstrakcyjnym w określonej formie [...]. Wyróżnione trzy elementy normy kompetencji prawodawczej: (1) wskazanie podmiotu - organu państwa, (2) ustanowienie uprawnienia lub obowiązku ustanowienia normy prawnej generalno-abstrakcyjnej, (3) określenie rodzaju aktu normatywnego, w którym norma prawna generalno-abstrakcyjna ma zostać wyrażona, stanowią konstytutywne elementy tej normy. Z tak rozumianą normą kompetencji prawodawczej moga być jednak związane dodatkowe obowiązki spoczywające na organie państwa, któremu przysługuje kompetencja prawodawcza. Obowiązi te, w postaci nakazów lub zakazów, mogą dotyczyć zasad realizowania kompetencji prawodawczej lub warunków, jakie musi spełniać rezultat procesu realizacji kompetencji prawodawczej" ${ }^{21}$.

Kompetencje prawodawcze organów jednostek samorządu terytorialnego dotyczą aktów prawa miejscowego. Akty te podejmowane są w formie uchwał organów kolegialnych lub zarządzeń organów monokratycznych. Skoro akty te podlegają kontroli sądowoadministracyjnej (art. $3 \S 2$ pkt 5 Prawa o postępowaniu przed sądami administracyjnymi), a działalność samorządów podlega nadzorowi organów nadzoru na podstawie kryterium zgodności z prawem ${ }^{22}$, to powstaje zasadnicze pytanie o zakres kontroli, a także o to, w jaki sposób powinna być dokonywana kontrola realizowania kompetencji prawodawczych przez organy jednostek wspólnot samorządowych.

Gdy chodzi o kwestie zakresu kontroli w stosunku do aktów prawa miejscowego organów jednostek samorządu terytorialnego, niewątpliwie w pierwszej kolejności konieczne jest skontrolowanie prawidłowości odkodowania przez organ upoważnienia do działania i zakresu tego upoważnienia, następnie podejmowania przez ten organ działania w granicach upoważnienia, a wreszcie sposobu realizowania upoważnienia z perspektywy zadań kierowanych do organu $\mathrm{w}$ tym zakresie przez ustawodawcę. W procesach tworzenia prawa nie następuje indywidualizacja ani konkretyzacja ogólnej i abstrakcyjnej normy materialnego prawa administracyjnego, w taki sposób jak ma to miejsce $\mathrm{w}$ procesach stosowania prawa. Skoro zatem takie realizowanie tego rodzaju norm w procesach tworzenia prawa nie ma miejsca, to nie jest również objęte kontrolą sądowoadministracyjną i nadzorem sprawowanym przez organy nadzoru.

Jak wyżej sygnalizowano, przepisy, w których zakodowano normy kompetencyjne i zadaniowe, podlegają ścisłej wykładni, a kompetencji i zadań organów administracji nie wolno domniemywać. Te podstawy normatywne każdej kompetencji administracyjnej należy odczytywać wprost, bez sięgania - zwłaszcza w przypadku norm kompetencyjnych - do innych niż językowa metod wykładni, a przy odkodowywaniu norm zadaniowych bardzo ostrożnie posługiwać się pozajęzykowymi metodami wykładni.

${ }^{21}$ M. Bogusz, Wadliwość aktu prawa miejscowego, Gdańsk 2008, s. 62 i n.

${ }^{22}$ Art. 85 ustawy o samorządzie gminnym, art. 76 ust. 1 i art. 77 ustawy o samorządzie powiatowym, art. 78 ust. $1 \mathrm{i}$ art. 79 ustawy o samorządzie województwa. 
Gdy chodzi o wskazanie sposobu, w jaki sąd administracyjny i organ nadzoru powinny dokonywać kontroli realizowania kompetencji prawodawczych przez organy jednostek wspólnot samorządowych, oczywiste wydaje się dążenie do tego, aby kontrola ta była wykonywana w sposób pełny. Oznacza to, że kontrola nad działalnością prawodawczą wspólnot samorządowych nie powinna poprzestawać na stwierdzeniu istnienia upoważnienia i odnotowaniu nieprzekroczenia przez organ w swoim działaniu granic tego upoważnienia. Konieczne jest również zbadanie sposobu czynienia użytku z upoważnienia ustawowego, co przedstawia się jako szczególnie istotne, gdy uwzględni się wyżej prezentowane uwagi na temat atrybutu samodzielności wspólnot samorządowych. Kontrola taka jest możliwa jedynie wtedy, gdy na organach spoczywa normatywny obowiązek zaprezentowania motywów ich działania. Konieczne jest zatem odnalezienie normy stanowiącej źródło takiego obowiązku. Jak wyżej sygnalizowano, podstawą takiego obowiązku są normy określające sposób i formę działania, co oznacza konieczność odkodowania takich właśnie norm.

O ile normy kompetencyjne i zadaniowe podlegają ścisłej wykładni, o tyle nie ma przeszkód, aby w stosunku do norm określających sposoby i formy działania, tj. norm o roli służebnej wobec norm prawa materialnego, stosować metodę tzw. pełnej wykładni ${ }^{23}$. Brak wyraźnej regulacji - na kształt unormowań Kodeksu postępowania administracyjnego - w zakresie standardów formalnoprawnych, jakim powinny odpowiadać akty prawa miejscowego, nie wyklucza możliwości systemowego i celowościowego odczytywania tych standardów, a zwłaszcza nie uzasadnia akceptowania jako zachowania legalnego arbitralności organów jednostek samorządu terytorialnego w realizowaniu przez nie ich kompetencji prawodawczych tylko z tego powodu, że brakuje w systemie prawnym w stosunku do aktów prawa miejscowego regulacji analogicznej do unormowania art. $107 \S 1$ i 33 k.p.a.

\section{VII}

Analiza poglądów doktryny i orzecznictwa sądowoadministracyjnego ugruntowuje w przekonaniu o zasadności i potrzebie posługiwania się metoda pełnej wykładni w odkodowywaniu normatywnego obowiązku organów jednostek samorządu terytorialnego w podejmowaniu aktów prawa miejscowego w formie (uchwał lub zarządzeń) obejmującej nie tylko samo rozstrzygnięcie wykreowane w procesie prawodawczym, lecz także jego uzasadnienie.

${ }^{23} \mathrm{~W}$ doktrynie prawa administracyjnego postulat tzw. pełnej wykładni został zaprezentowany przez E. Smoktunowicza. Zob. idem, Clara non sunt interpretanda w prawie administracyjnym, w: Księga pamiatkowa profesora Eugeniusza Ochendowskiego, Torun 1999, s. 304. Przez pojęcie „pełnej wykładni” rozumiem proces interpretacyjny prowadzony równolegle za pomoca wszystkich typów dyrektyw (tj. dyrektyw językowych, systemowych i funkcjonalnych) bez zakładania z góry pierwszeństwa i szczególnego znaczenia wykładni językowej w stosunku do pozostałych metod wykładni, z zastrzeżeniem, że wprawdzie od wykładni językowej rozpoczyna się proces wykładni, ale na niej się nie kończy. 
W doktrynie obowiązek uzasadnienia uchwały (tam, gdzie obowiązek ten nie jest wyraźnie określony ustawowo) wyprowadzany jest z ogólnej zasady ustrojowej związania organów administracji prawem, obowiązu odwoływania się do prawa oraz z kompetencji sądów administracyjnych i organów nadzoru, które - sprawując kontrolę - muszą znać motywy, jakimi kierowała się rada gminy, powiatu czy sejmik, a także z zasady demokratycznego państwa prawnego i zasad szczegółowych, w tym zasady zaufania do państwa i stanowionego przez nie prawa czy zasad „dobrej legislacji” ${ }^{24}$. Z kolei w orzecznictwie sądowoadministracyjnym podnosi się, że „w procesie interpretacji kompetencji władzy publicznej przepis art. 7 Konstytucji RP, stanowiący, że organy władzy publicznej działają na podstawie i w granicach prawa, wiąże się z zasadą zaufania do państwa, wynikająca z zasady demokratycznego państwa prawnego (art. 2 Konstytucji). Działanie organu władzy publicznej, mieszczące się w jego prawem określonych kompetencjach, ale noszące znamiona arbitralności i niepoddające się kontroli i nadzorowi, nie może być uznane za zgodne z prawem. Obowiązek działania na podstawie prawa, w połączeniu z zasadą zaufania, stwarza po stronie organów władzy publicznej obowiązek uzasadniania jej rozstrzygnięć. Obowiązek taki jest zaliczany do standardów demokratycznego państwa prawnego. Obowiązek uzasadniania uchwał rady gminy jest też elementem zasady jawności działania władzy publicznej”25. Podkreśla się, że „żadne rozstrzygnięcie organu publicznego w demokratycznym państwie prawnym nie może być arbitralne (art. $2 \mathrm{w}$ związku z art. 7 Konstytucji RP). Im bardziej uznaniowe jest rozstrzygnięcie, tym ważniejsze jest przestrzeganie obowiązku sporządzenia uzasadnienia. Wymóg uzasadnienia uchwały [...] wynika z zasady zaufania do państwa i zasady dobrej legislacji wyprowadzanych z zasady demokratycznego państwa prawa - art. 2 Konstytucji RP”26.

Mając na uwadze treść art. $147 \S 1$ Prawa o postępowaniu przed sądami administracyjnymi (zgodnie z którym sąd, uwzględniając skargę na uchwałę lub akt, o których mowa w art. $3 \S 2$ pkt 5 i 6 ustawy, stwierdza nieważność tej uchwały lub aktu w całości lub w części albo stwierdza, że zostały wydane z naruszeniem prawa, jeżeli przepis szczególny wyłacza stwierdzenie ich nieważności), a także odpowiednie regulacje wszystkich trzech ustaw samorządowych (zgodnie z którymi przesłanką stwierdzenia nieważności uchwały organu jednostki samorządu terytorialnego jest istotna sprzeczność uchwały z prawem ${ }^{27}$ ), oraz stanowisko judykatury (według którego do istotnych naruszeń prawa w rozumieniu tych unormowań należy naruszenie: przepisów wyznaczających kompetencję do podejmowania uchwał, podstawy prawnej podejmowania uchwał, przepisów prawa ustrojowego, przepisów prawa materialnego - przez wadliwą ich wykładnię - oraz przepisów regulujących proce-

${ }_{24}$ M. Stahl, Samorzad terytorialny w orzecznictwie sqdowym. Rozbieżności i watpliwości, „Zeszyty Naukowe Sądownictwa Administracyjnego" 2, 2006, nr 6(9), s. 45.

${ }^{25}$ Por. np. wyroki NSA: z 8 czerwca 2006 r., II OSK 410/06, Lex, nr 247924; z 8 kwietnia 2009 r., II OSK 1468/08, Lex, nr 490933; z 1 lipca 2009 r., II OSK 400/09, Lex, nr 555875; z 1 grudnia 2009 r., II OSK 1431/09, Lex, nr 580915; z 16 lutego 2011 r., II OSK 2420/10, Lex, nr 1071215; z 5 marca 2009 r., II OSK 1824/08, Lex, nr 597395.

${ }^{26}$ Wyrok NSA z 12 lipca 2012 r., II OSK 1154/12, Lex, nr 1251758.

${ }^{27}$ Art. 91 ust. 1 i 4 ustawy o samorządzie gminnym. 
durę podejmowania uchwał ${ }^{28}$ ), należy przyjąć, że brak sporządzenia u zas a dnienia uchwały może w konkretnej sytuacji prowadzić do stwierdzenia nieważności uchwały, jeżeli nie jest możliwe ustalenie w inny sposób motywów jej podjęcia ${ }^{29}$. Zwłaszcza dla oceny motywów działania organu nie może być wystarczająca sama treść uchwały, z której nie wynikają racje, jakimi kierował się organ podejmujacy rozstrzygnięcie skierowane do adresatów stojących na zewnątrz administracji i dotyczące ich sytuacji prawnej.

\section{VIII}

Przedstawione wyżej uwagi na temat znaczenia, jakie dla prawidłowego realizowania kompetencji administracyjnych ma świadomość ich podstaw normatywnych, nie pozwalają zaakceptować takich stanowisk, które to znaczenie bagatelizują bądź nie wiążą z nim adekwatnych skutków prawnych. Dotyczy to zwłaszcza kompetencji prawodawczych organów jednostek samorządu terytorialnego, gdzie nieprawidłowe pojmowanie atrybutu samodzielności wspólnot samorządowych wykorzystywanego często jako argument mający decydować o władztwie wspólnoty (przy jednoczesnym braku wyraźnie wyartykułowanego przez ustawodawcę obowiązku uzasadniania w formalny sposób aktów prawa miejscowego, który to obowiązek trzeba dopiero wyprowadzać w drodze procesów wykładni), może stanowić realne zagrożenie dla prawidłowego realizowania tych kompetencji, a w konsekwencji niebezpieczeństwo tworzenia prawa w sposób dowolny i arbitralny. Zagrożenie to wzrasta, gdy dodatkowo uwzględni się nie zawsze poprawne działania ustawodawcy w kreowaniu norm zadaniowych kierowanych do organów administracji publicznej, co w konsekwencji nierzadko stwarza problemy w odkodowywaniu przez organy tych norm wraz z ich percepcja.

\section{IX}

Dla zilustrowania powyższych uwag w odniesieniu do konkretnego przykładu warto przywołać poglądy, jakie kształtują się na tle spraw sądowoadministracyjnych ze skarg na uchwały podejmowane na podstawie art. XII $\S 1$ ustawy z 26 czerwca 1974 r. - Przepisy wprowadzające Kodeks pracy ${ }^{30}$, zgodnie z którym „dni i godziny otwierania oraz zamykania placówek handlu detalicznego, zakładów gastronomicznych i zakładów usługowych dla ludności określa gmina”. Z przepisu tego wynika upoważnienie do określania dni i godzin otwierania i zamykania wskazanych wyżej placówek. Ustawodawca

${ }^{28}$ Wyrok NSA z 11 lutego 1998 r., II SA/Wr 1459/97, Lex, nr 33805; wyrok WSA w Warszawie z 26 września 2005 r., IV SA/Wa 821/05, Lex, nr 192932.

${ }_{29}$ Zob. wyrok NSA z 8 kwietnia 2009 r., II OSK 1468/08, Lex, nr 490933.

${ }^{30}$ Dz. U. 1974, Nr 24, poz. 142 ze zm. 
jednak nie określił czytelnie, w jaki sposób organy powinny realizować to upoważnienie. W orzecznictwie sądowoadministracyjnym, dostrzegając ten stan rzeczy, przyjęto, że mimo to nie można poprzestać na konstatacji, że organy samorządu terytorialnego mają niczym nieskrępowaną swobodę $\mathrm{w}$ stanowieniu prawa miejscowego w oparciu o art. XII § 1 Przepisów wprowadzających Kodeks pracy, trafnie podkreślając, że przyznanie gminie pełnej swobody prawotwórczej w tym zakresie mogłoby prowadzić do naruszenia jednej z podstawowych zasad konstytucyjnych, tj. zasady wolności gospodarczej poprzez jej dowolne ograniczanie przez organy gmin ${ }^{31}$, a dopuszczalny zakres prawotwórstwa lokalnego na podstawie art. XII § 1 Przepisów wprowadzajacych Kodeks pracy uwzględniać musi jedna z fundamentalnych zasad, a mianowicie to, że akty prawa miejscowego to zawsze akty podustawowe, o charakterze wykonawczym do ustawy.

Wychodząc z założenia, że przepis wykonawczy może ze swej istoty jedynie „wykonywać” ustawę, a więc ją uzupełniać, nie może natomiast regulować materii, która nie była przedmiotem ustawy, traci bowiem wówczas swój wykonawczy charakter (staje się samodzielnym źródłem prawa i wykracza w ten sposób poza granice upoważnienia ustawowego), przyjęto, że skoro stanowione w oparciu o podstawę prawną z art. XII $§ 1$ Przepisów wprowadzających Kodeks pracy akty prawa miejscowego muszą tę ustawę „wykonywać”, to musza się one mieścić w przedmiocie regulacji tej ustawy. Wskazuje się, że przepis ten zapełnia lukę, jaka powstała w zwiąku z pozbawieniem przez unormowania powyższej ustawy mocy obowiązujacej ustawy z 14 kwietnia 1967 r. o godzinach otwarcia placówek handlu detalicznego, zakładów gastronomicznych i zakładów usługowych dla ludności oraz o rozkładzie czasu pracy pracowników w nich zatrudnionych ${ }^{32}$, która zawierała m.in. przepisy upoważniające ówczesne terenowe organy administracji państwowej do określania godzin otwierania i zamykania placówek handlu detalicznego, zakładów gastronomicznych i zakładów usługowych oraz sankcje na wypadek naruszenia tak określonych godzin. W konsekwencji w orzecznictwie przyjęto, że przepis art. XII § 1 ma w istocie wykonywać, a więc uzupełniać Kodeks pracy, a rada gminy stanowiąc na podstawie tego przepisu godziny otwarcia i zamknięcia tych placówek, każdorazowo winna uwzględnić, że wydawane przez nią przepisy stanowią regulację praw i obowiązków pracodawcy i pracowników, a więc materię ściśle związaną z prawem pracy. Taka jest zatem treść normy zadaniowej określającej sposób czynienia użytku przez organ gminy z kompetencji wynikającej z art. XII § 1 ustawy Przepisy wprowadzające Kodeks pracy.

Podkreśla się także, że stanowiąc prawo miejscowe na podstawie art. XII $\S 1$ Przepisów wprowadzających Kodeks pracy, organy gminy uwzględniać też muszą każdorazowo podstawowe zasady konstytucyjne, prawo miejscowe jako prawo podustawowe musi być bowiem zgodne nie tylko z przepisami ustawy, na podstawie której jest stanowione, ale także z przepisami wyższej rangi, w tym zwłaszcza z treścią Konstytucji. Z kolei jedna z podstawowych zasad obecnej Konstytucji RP z 2 kwietnia 1997 r. jest zasada wolności gospodarczej

${ }^{31}$ Wyrok WSA w Lublinie z 15 listopada 2005 r., III SA/Lu 532/05, Lex, nr 394863.

${ }^{32}$ Dz. U. 1967, Nr 13, poz. 56. 
(art. 20 i 22 oraz art. $64 \S 1$ i art. $65 \S 1$ ). Wreszcie przyjęto, że za niezgodny z prawem uznać należy wydany na podstawie art. XII § 1 Przepisów wprowadzających Kodeks pracy taki akt prawa miejscowego, co do którego nie sposób ustalić, czy wydający go organ kierował się przesłankami przewidzianymi $\mathrm{w}$ ustawie stanowiącej podstawę prawną do jego wydania, a więc czy stanowi on prawidłowy akt wykonawczy do tej ustawy, zgodny z jej celami i uszczegółowiający zawarte w niej regulacje. W konsekwencji brak uzasadnienia aktu prawa miejscowego przy jednoczesnej niemożliwości ustalenia motywów działania organu na podstawie całokształtu dokumentacji związanej z procesem uchwalania tego aktu prowadzi do konkluzji, że nie jest możliwe przyjęcie, że akt ten mieści się w zakresie upoważnienia ustawowego zawartego w art. XII $\S 1$ Przepisów wprowadzajacych Kodeks pracy, co uzasadnia stwierdzenie jego nieważności ${ }^{33}$.

Należy jednak odnotować również stanowisko, według którego dopuszczalna jest wyłącznie językowa wykładnia przepisu art. XII $§ 1$ Przepisów wprowadzajacych Kodeks pracy, a zwłaszcza nie jest uprawnione systemowe interpretowanie tego przepisu. W rozwinięciu tego poglądu przyjęto, że „stwierdzenie nieważności uchwały może mieć miejsce tylko w sytuacji, gdy taka uchwała narusza przepisy ustaw wprost nakazujace zrealizować dyspozycję ustawy. W innych przypadkach takie działanie jest niedopuszczalne, bo wiąże się z ograniczeniem samodzielności uchwałodawczej gminy, a to jest wkroczeniem w wartość chronioną konstytucyjnie. [...] Z taką sytuacją mielibyśmy do czynienia wówczas, gdy kontrolowana uchwała wyraźnie odnosiłaby się do celów spoza prawa pracy i to wynikałoby z jej treści lub uzasadnienia albo dałoby się ustalić na podstawie materiałów towarzyszących jej podjęciu. [...] Podstawa stwierdzenia nieważności uchwały nie może być domniemywana, zatem nie do przyjęcia jest stanowisko, że brak uzasadnienia uchwały, które wskazywałoby na cel jej podjęcia, jest tego typu naruszeniem, które powinno skutkować jej nieważnościa. Niewątpliwie brak uzasadnienia lub niemożność ustalenia celu w oparciu o materiały związane z podjęciem uchwały to wady postępowania uchwałodawczego, ale nie mogą być one, w ocenie NSA, traktowane jako tego rodzaju wadliwość, skutkiem której może być stwierdzenie nieważności. Skoro przepisy ustawy dla uchwał podejmowanych na podstawie art. XII $§ 1$ Przepisów wprowadzajacych Kodeks pracy nie nakładają obowiązku uzasadniania uchwał, a brak jest również przepisów ogólnych, które konstytuują taki obowiązek, to w konsekwencji tego rodzaju wada nie daje podstaw do orzeczenia o nieważności uchwały. Przyjęcie stanowiska odmiennego narusza przepisy prawa" ${ }^{4}$.

${ }^{33}$ Wyroki WSA w Krakowie: z 14 marca 2013 r., III SA/Kr 1320/12, Lex, nr 1303109; z 14 marca 2013 r., III SA/Kr 1616/12, Lex, nr 1303110; z 21 maja 2013 r., III SA/Kr 1815/12, Lex, nr 1317204; z 16 maja 2013 r., III SA/Kr 1760/12, Lex, nr 1317202; D. Dąbek, Glosa do wyroku WSA w Lublinie z dnia 15 listopada 2005 r., III SA/Lu 532/05, „Administracja” 2006, nr 3, s. 151 i n.; wyrok WSA w Lublinie z 28 kwietnia 2014 r., III SA/Lu 107/14; Lex, nr 1506533; wyroki NSA z 4 kwietnia 2008 r., II GSK 477/07, Lex, nr 381675; z 27 marca 2014 r., II GSK 86/13, Lex, nr 1488154; z 2 grudnia 2014 r., II GSK 1612/13, Centralna Baza Orzeczeń Sądów Administracyjnych, http://orzeczenia.nsa.gov.pl.

${ }^{34}$ Wyrok NSA z 2 grudnia 2014 r., II GSK 1612/13, Centralna Baza Orzeczeń Sądów Administracyjnych, http://orzeczenia.nsa.gov.pl. 
Pogląd powyższy skutkujący koniecznością oddalenia skargi, a tym samym stwierdzenia legalności aktu prawa miejscowego, którego treść może sprowadzać się wyłącznie do wskazania dni i godzin otwierania i zamykania placówek, nie znajduje oparcia ani w argumentacji nawiąujaccej do atrybutu samodzielności wspólnot samorządowych, ani w argumentacji, według której brak unormowania określającego wymogi sporządzania uzasadnienia uchwały stanowiącej akt prawa miejscowego nie pozwala wyprowadzić tego elementu formalnego uchwały w drodze wykładni systemowej. Argumentacja ta - choć sama jest arbitralna - zmierza do zaakceptowania działań prawotwórczych organów administracji jako legalnych tylko dlatego, że bez głębszej refleksji dopuszcza się wyjęcie ich spod pełnej kontroli sądowoadministracyjnej. Takie stanowisko orzecznictwa może być odczytywane jako zachęta do arbitralnego i dowolnego realizowania kompetencji prawodawczych, skoro z powodów formalnych nie będzie możliwe skontrolowanie legalności czynienia użytku $\mathrm{z}$ tych kompetencji.

prof. dr hab. Wojciech Jakimowicz

Uniwersytet Jagielloński

\section{NORMATIVE DETERMINANTS OF THE EXERCISE OF LEGISLATIVE COMPETENCES BY SELF-GOVERNMENT BODIES}

\section{Summary}

This work seeks to analyse the normative determinants of the exercise of administrative power by local self-government units within their legislative competences. The influence of the normative autonomy of local self-government units on the exercise of legislative competences by their different bodies is presented. Among the normative determinants of exercising legislative competences, special attention is paid to the form of competence and task norms, including their mutual relations. The methods of interpretation of such norms are pointed out. An assessment of the impact of norms which determine the formal aspect of using delegation of legislative power on the manner of exercising legislative competences is also made. The considerations described in the paper were based on the views presented in the doctrine of law and illustrated by examples of selected judicial decisions. 